\title{
The Association between Self-efficacy of Saudi Learners and Their EFL Academic Performance
}

\author{
Fakieh Alrabai \\ Department of English Language, King Khalid University, Abha, Saudi Arabia
}

\begin{abstract}
Considering the important impact of individual variables on language learning, this study seeks to highlight the relationship between Saudi learners of English as a foreign language (EFL) sense of self-efficacy about learning English and their academic performance in this language. The self-efficacy beliefs of 221 Saudi EFL undergraduate students whose major is English were explored using a questionnaire, while their academic performance was assessed using final exam scores in four language skills (listening, speaking, reading, and writing). The data gathered were analysed quantitatively. The findings demonstrated that EFL participating students hold very low overall self-efficacy beliefs about learning the English language. They were also low achievers in learning English in general. Moreover, students' English self-efficacy positively correlated with their language attainment, suggesting that learners' beliefs about language learning affect their language performance. The findings of the study shed light on the crucial association between Saudi EFL learners' self-efficacy beliefs and their language achievement. We anticipate that these findings will provide guidelines for the different parties involved in language learning/teaching in the country. These guidelines should address how to help students hold correct beliefs about foreign language learning in order to achieve better EFL learning outcomes.
\end{abstract}

Index Terms - self-efficacy, academic performance, mastery experience, vicarious experience, physiological state

\section{INTRODUCTION}

\section{A. The Concept of Self-efficacy}

Bandura (1986, p.392) conceptualized self-efficacy as "one's belief in his ability to organize and accomplish the required tasks to manage the upcoming circumstances". In a similar vein, Pajares (1996) perceived self-efficacy as a person's subjective convictions to successfully learn or complete a specific task given the skills he/she processes. Bandura (1997, p. 3) extended the definition of self-efficacy to be "a belief in one's capabilities to organize and execute courses of action required to produce given attainments".

Self-efficacy is considered a central component of social cognitive theory, which presumes that human beings have cognitive abilities to self-organize, self-reflect, self-regulate, and determine their own social destiny based on the changes in the environment that surround them. Pajares (2009) acknowledges this fact by explaining that self-efficacy is a key element of social cognitive theory in that people must recognize themselves and their capabilities in order to control their actions. According to him, self-efficacy beliefs provide a solid foundation for promoting human motivation, well-being, personal accomplishments, and risk-taking, as well as for lowering levels of anxiety.

Branscombe and Baron (2016) categorize self-efficacy into three main types: self-regulatory (self-efficacy that includes the ability to resist peer pressure and avoid high-risk activities), social (self-efficacy that includes the ability to form and maintain relationships, to be confident and involved in free time activities), and academic (self-efficacy that includes the ability to efficiently continue the course work, manage learning activities, and meet one's own expectations).

\section{B. Significance of Self-efficacy}

Given the strong influence of self-efficacy on various aspects of learning variables such as motivation, behaviour, and academic performance, the past few years have seen a growing interest in self-efficacy research in the field of education. From a general perspective, Siegle (2000) stated that self-efficacy is dependent on the ability to attempt the task and specifies the student's assertiveness to attempt a certain type of task. With respect to language learning, the self-efficacy beliefs of the learner play a premium role in learning non-primary languages. This construct is said to be strongly associated with language learner's behaviours (e.g., choice behaviour), the degree to which students pursue language learning tasks (i.e., whether or not they believe they are sufficiently capable to execute or, inversely, step away from it), and the amount of effort applied by an individual as well as his/her determination in language learning. Apart from choice behaviour and the effort, self-efficacy not only influences how much effort is applied but also affects how productive the effort turns out to be. Further, a person's thoughts and emotional reaction are dependent on self-efficacy. The feeling of calm and tranquillity is felt by individuals with a high degree of self-efficacy while attempting a task and; conversely, an individual with low self-efficacy feels the task to be more strenuous than it actually is (Pajares, 1996). According to Pajares and Valiante (1997), such students' beliefs about their academic capabilities largely affect their 
acquired knowledge and skills mastery and may either help or hinder the development of language (Pintrich \& Schunk, 1996).

Self-efficacy beliefs can positively or negatively affect the process of language learning. On the positive side, high self-efficacy increases the sense of achievement and well-being in students (Siddiqui, 2015). Highly efficacious learners put more effort into the task and, when difficulties or hardships arise, they conveniently become more determined to overcome obstacles (Herron et al, 2006). Moreover, self-efficacy helps students pursue tasks with confidence, enables them to set difficult goals and higher personal standards, develop problem-solving techniques, become willing to take on challenging tasks, and they exhibit lower levels of anxiety as well (Schunk, 1990). Furthermore, students with higher self-efficacy demonstrate higher motivation (Schunk, 1991) and deliver better learning results (Schunk and Pajares, 2002).

On the negative side, students who hold low self-efficacy beliefs do not like to face challenges and usually avoid difficult tasks (Schunk, 1990) because they consider their low ability to be inborn (Bernhardt, 1997). Believing that they have low aptitude by birth, low self-efficacious students tend to tackle easy tasks with a low level of difficulty and often set simple and short-term goals (Tremblay \& Gardner, 1995). Such students usually attempt tasks with uncertainty and tend to become anxious and stressed because they always view difficult tasks as threatening (Bandura, 1997). Those learners typically feel the stress of failure from initiating learning tasks due to a lack of confidence. They also always have the fear of failure, which forces them to have a weak commitment to accomplishing the required tasks.

\section{Sources of Self-efficacy}

Blumenthal (2014) states that the self-efficacy of a learner is influenced by both internal and external factors. The social environment of a learner is considered an external factor, while the learner's personal traits are internal factors, both of which are significant variables that fashion his/her efficacy beliefs.

According to Bandura (1997), there are four main sources of learner self-efficacy: Mastery experience, Vicarious experience, Verbal persuasions, and Physiological and affective states. Usher (2009) recognized Mastery experience (i.e., one's own previous experiences and performances) as the most powerful among the four primary sources. Vicarious experience (i.e., socially comparing one's self to other people having similar capabilities and considering them as role models to hold the belief that we also possess the capabilities to master the activities necessary for success) is the second source of self-efficacy. The third source of learner self-efficacy is Verbal persuasions (i.e., affirming one's belief verbally - through positive self-talks - that he/she is capable of mastering certain activities). Finally, Physiological and affective states (i.e., anxiety, stress, arousal, fear reactions, tension, nervousness and tiredness, are all emotions that can either reduce, or conversely, boost confidence in our capabilities).

Zuo and Wang (2016) acknowledge the four sources proposed by Bandura (1997) and suggest that the major factors that influence participants' self-efficacy beliefs to use English are past performance, peers' and advisors' influence, social persuasions, and emotional and physiological states, in addition to self-awareness of English proficiency, familiarity with the task and its level of difficulty, and interest in learning.

\section{The Relationship between Self-efficacy and EFL Academic Performance}

Self-efficacy has been found to be positively connected to students' academic achievement within the educational setting (Pajares \& Miller, 1995; Pajares, Miller, \& Johnson, 1999; Pajares \& Valiante, 1997; Zimmerman, 1995; among others).

Only a few self-efficacy studies have been applied to the field of language learning (see e.g. Multon, Brown, \& Lent, 1991; Chen, 2007, etc.). Investigations in this area have examined the relationship between self-efficacy and the general competence of a language learner as well as the achievement in specific language skills in relation to learner self-efficacy. In their study, Mahyuddin and her associates (2006) identified a positive correlation between students' self-efficacy and their English language achievement. The authors concluded that achievement in the English language improves when students have high self-efficacy. Additionally, Ayoobiyan and Soleimani (2015) explored the relationship between Iranian medical students' self-efficacy and their language proficiency. The authors established a positive and very strong correlation between students' language proficiency and their self-efficacy in that students with higher self-efficacy tended to have higher language proficiency.

Mills, Pajares, and Herron (2006) led a study that examined the relationship between learner self-efficacy and specific skills in language learning. For male students, there was a relationship between reading self-efficacy and reading proficiency, while for female students, the relationship was between listening self-efficacy and listening proficiency.

The impact of English listening self-efficacy, English anxiety, the perceived value of the English language and culture on EFL learners' performances was the subject of investigation by Chen (2007). The results indicated that English listening self-efficacy predicts English listening performance better than do language anxiety, perceived value of the English language and culture.

Huang and Chang (1998) conducted another study on the relationship between reading and writing self-efficacy and achievement with four ESL students from the highest level of reading and writing classes. The participants' self-efficacy has been found to affect their writing performance.

Chen and Lin (2009) investigated the predictors of success in an English language-writing test. The main findings 
were that high achievers demonstrated high levels of self-efficacy and similarly low levels of anxiety.

The results from the aforementioned studies evaluating the association between self-efficacy and performance in language learning confirm the vital importance of the self-efficacy variable in learning a second/foreign language.

\section{E. Statement of the Problem}

Considerable research has been devoted to the study of self-efficacy in educational settings with results demonstrating a positive relationship between self-efficacy beliefs and academic achievement. However, a thorough search of related literature reveals that research on language self-efficacy is still very rare in Saudi Arabia, if performed at all. To the best knowledge of the researcher, the study of Abdelhafez and Zaki (2016) was the only one that investigated Saudi learners' self-efficacy. Using two scales (the EFL self-efficacy and the EFL identity), this study explored the relationship between EFL learners' self-efficacy and identity and sought to identify gender differences among a sample of 320 male and female EFL undergraduate university students at two state universities in Saudi Arabia and Egypt. The authors reported a significant correlation between learners' self-efficacy and their identity. The study sub-groups differed in all dimensions of identity (except the social dimension) and favoured the female and Egyptian groups.

To our knowledge, we are not aware of any study investigating the predictive power of self-efficacy beliefs of achievement in English as a foreign language for Saudi students. This study therefore aims primarily to explore the self-efficacy perceptions of the Saudi EFL college-level learners' and investigate whether this knowledge reveals connections between learners' beliefs and their achievement in English as a foreign language.

\section{F. Significance of the Study}

This study holds a pedagogical significance that gives recognition to the possible association between students' self-efficacy and foreign language achievement in the eyes of the different stakeholders of the EFL process in Saudi Arabia (EFL learners, teachers, and curriculum developers). Knowing how the student perceives him/herself directs the planning and implementation of the best learning strategies, thereby decreasing the negative thoughts about their own abilities. In light of the anticipated findings of this study, teachers of English in schools, institutes, university professors, etc., can study the positive or negative impacts efficacy may have on achievement and enhance the learners' language proficiency by developing the positive and minimizing the negative. Furthermore, the study outcomes may be of great assistance to language-teaching professionals and material developers in Saudi Arabia in guiding the development of appropriate courses for English language learning and subsequently contribute to the creation of improved English language programmes in the country.

\section{G. Main Objectives of the Study}

The main objectives of the study are the following:

a. Identifying the degree of self-efficacy and EFL achievement of English-majoring university students in Saudi Arabia.

b. Identifying the association between self-efficacy and academic achievement of EFL university students in Saudi Arabia.

\section{H. Questions of the Study}

1. What is the degree of self-efficacy and EFL achievement of the English language learners in Saudi Arabia?

2. What association exists amongst the learners' self-efficacy in Saudi Arabia and their EFL achievement?

\section{Methods AND Design}

Quantitative research was conducted in order to determine the degree of the learners' self-efficacy for learning English and to identify the degree of the association between learners' self-efficacy in Saudi Arabia and their achievement in the English language.

\section{A. The Study's Subjects and Context}

A total of 221 (108 male and 113 female) participants were recruited from one tertiary EFL context (King Khalid University in the south of Saudi Arabia) for the study. All were English-majoring university students between the ages of 18 and 27 years. These students were in the first four levels where the courses taught focus mainly on the four language skills (listening, speaking, reading, and writing). All the participants were Saudi nationals with Arabic as their native language. The undergraduate English language programme at King Khalid University offers a variety of linguistics, translation, and literature courses, which together provide the student with a good command of English and sound knowledge in various cognitive, interpersonal, communication, and psychomotor skills.

\section{B. Measurements and Procedures}

An online Arabic-language students' survey was employed in this study. The 32-questions scale examined learners' assessment of their capabilities to master certain skills while learning English as a foreign language on a 7-point Likert-type rating scale ranging from 1 (I cannot do it at all) to 7 (I can do it very well). The scale was designed to 
measure the learners' efficacy in the following four skills: (a) self-efficacy for listening (Items 1, 3, 9, 10, 15, 22, 24, and 27); (b) self-efficacy for speaking (Items 4, 6, 8, 17, 19, 20, 23, and 30); (c) self-efficacy for reading (Items 2, 12, 16, 21, 25, 26, 29, and 32); and (d) self-efficacy for writing in English (Items 5, 7, 11, 13, 14, 18, 28, and 31). Most of the items in this survey were adopted form The Questionnaire of English Self-Efficacy (QESE) developed by Wang (2004), and Wang et al. (2013), while others were developed mainly for this research based on the research scope and to make it applicable to the target population and context.

The items of the questionnaire were translated into Arabic so that the participants would understand it and use it with ease (for the Arabic and the original English-language version, see the Appendix). Three Arabic-speaking experts verified the translation. To establish the reliability of the instruments used to collect data, the efficacy tool was piloted with 43 volunteer university students prior to the main stage of the study. The Cronbach alpha coefficient was .96, confirming the reliability of the instrument and its readiness to be used in the main study. The face validity of the survey was confirmed because the survey utilized in this study was mainly adopted from earlier studies that had confirmed the survey is a valid measure of the qualities it is designed to measure.

During the design process, the online survey was created to be visually appealing to encourage the potential participants to finish the entire survey. Words and expressions that are simple, direct, and familiar to the targeted respondents were used in the survey.

An invitation along with comprehensive details about the research was sent to the potential participants in the semester preceding the semester of data collection. Those participants who confirmed their participation were provided with a link to the survey items and guidelines on how to complete the survey. Participants were assured at different stages of the study that their participation was completely voluntary and that they could withdraw at any stage if they so desired. Furthermore, they were reassured that their responses and the information collected would be entirely confidential and used exclusively for the purposes of this research. Participants completed the online survey in the computer labs at their institution. The survey was equipped with an indicator of progress (e.g., survey completion bar) to help the respondents determine how much of the survey they had completed. It took subjects approximately 30 minutes to complete the entire survey. After completing the survey, the participants received an acknowledgement message recognizing him/her for taking part in the study and confirming receipt of the survey. While responding to the survey, the researcher was also available to respond to any inquiries from the participants.

EFL achievement was measured by students' total score on the end-of semester unified exams that were designed to evaluate the mastery of four language skills (listening, speaking, reading, and writing). The total score for the end-of-semester exam is 50 (12.5 points for each skill), and the total mark for a learner is multiplied by 2 for a final score of 100 .

Listening skill was assessed using a listening comprehension test based on particular sets of situational recorded dialogues in the student's textbook. Students were required to answer multiple-choice questions to assess their comprehension of the main ideas and accurate information and to evaluate how they followed the development of arguments in the dialogues.

Speaking assessment involved evaluating the learner's ability to communicate by providing the student with a card that contained a topic that he/she had already studied during the semester. The candidate was then required to speak about it for approximately 2 minutes and to give short answers to questions. The student's ability to communicate was assessed based on certain criteria (how fluent the student was, how coherent were their ideas, how much vocabulary did the he/she possess and how well did they use it, how well the student used the language grammatical rules, how good was his/her pronunciation, etc.)

Achievement tests in reading assessed the students' reading comprehension skills, vocabulary knowledge, and spelling. Multiple-choice questions were given to assess the students' comprehension obtained through retrieving directly stated information, interpreting explicit and implied information as well as reflecting on texts. The learners' vocabulary was evaluated via word knowledge (e.g., synonyms and antonyms). Spelling was assessed through dictation whereby the teacher read a sentence aloud, which contained words that students had to spell.

Using essay tests and short-answer questions on general topics, writing tests evaluated the students' ability to organize ideas and use a range of vocabulary and grammar accurately. For essay grading, a criterion for appropriate responses to each essay question was developed followed by a scoring guide that explained what the scorer was seeking in each response and how much credit he/she intended to give for each part of the response.

A committee of four well-qualified teachers in the field of language education was assigned to mark the students' answers using unified answer sheets.

\section{Data Analysis}

To answer the first research question about the degree of self-efficacy and EFL achievement of Saudi language learners, frequencies, means and standard deviations for descriptive statistical analyses were deployed. Pearson correlation coefficients analysis was performed to identify the degree and the direction of the relationship between learners' self-efficacy and their EFL achievement (i.e., the second research question).

\section{FINDINGS AND DISCUSSION}


Based on the analysis of the study data, answers to the study questions were derived and presented in this section of the paper as follows:

1. What is the degree of self-efficacy and EFL achievement of English language learners in Saudi Arabia?

The degree of learner self-efficacy was calculated and categorized as follows: self-efficacy mean score above 6.30 out of 7 (> 90\%) was categorized as very high self-efficacy; a mean score ranging from 5.60 to 6.30 out of 7 (80 to $90 \%$ ) was categorized as high self-efficacy; a mean score from 4.90 to 5.60 out of 7 (70\% to $80 \%)$ was classified as moderate self-efficacy; a score from 4.20 to 4.90 out of 7 (60\% to $70 \%)$ was classified as low self-efficacy; and an efficacy score below $4.20(<60 \%)$ was classified as very low self-efficacy. The data in Table I below indicate that the overall mean score for learners' self-efficacy in this study was 3.82 out of 7 (54.57\%). In light of this result, participating learners in this study are considered very low-efficacious EFL learners.

TABLE I.

THE DEGREE Of LANGUAGE SELF-EFFICACY OF PARTICIPATING LEARNERS

\begin{tabular}{|l|l|l|}
\hline Variable & Mean & Standard Deviation \\
\hline Efficacy for Listening & 3.68 & .89 \\
\hline Efficacy for Speaking & 4.12 & .94 \\
\hline Efficacy for Reading & 3.80 & .86 \\
\hline Efficacy for Writing & 3.68 & .88 \\
\hline Overall Self-efficacy & 3.82 (out of 7) & .82 \\
\hline
\end{tabular}

Another significant finding is that participants demonstrated very low self-efficacy on all the four language skills, as can be seen in Table I. This finding verifies the relationship identified by earlier studies that recognized self-efficacy as the best predictor of learners' mastery in language skills (see e.g., Rahimi and Abedini, 2009; Asakereh and Dehghannezhad, 2015; Boakye, 2015; Pajares, 2003; among many others).

The mean scores reported in the appendix at the end of this paper reveal that participants did not score high efficacy on any of the items of the survey (5.6 out of $7,>80 \%)$. The participants established moderate efficacy on only one item in the entire survey: item \# 30 'Can you introduce yourself in English?' ( $M=5.00$ out of 7, 71.43\%); and low efficacy on six items (\# 2, 4, 11, 17, 21, and 27). Respondents demonstrated very low self-efficacy on the other twenty-five items in the survey, with item \# 18 'Can you produce English sentences with idiomatic phrases?' being the one with the lowest mean in the whole survey $(\mathrm{M}=2.78$ out of $7,39.71 \%)$; followed by item \# 28 'Can you post news in English on the internet?' $(\mathrm{M}=2.91$ out of $7,41.57 \%)$. Learners in this study appear to believe that their abilities were well below the competences required to perform the tasks required in these two items.

There are various hypotheses to explain the low self-efficacy of EFL learners in Saudi Arabia. Foremost is the contention that Saudi learners lack the fundamental basics necessary to have positive self-efficacy beliefs towards language learning. These basics include a learners' past performance (Mastery Experience), experiences with the performance of others (Vicarious Experience), persuasion from significant others (Social Persuasion), and physiological and emotional conditions (Psycho-physiological State).

One very important source of self-efficacy that Saudi language learners usually lack is the Mastery Experience. This is a well-known fact about most Arab learners of the English language. Rabab'ah (2003) argues that the most noticeable problems that impede the progress of Arab students at the university level can be attributed to the "inadequate mastery of the four language skills; namely, listening, speaking, reading and writing, p.186". Alaraj (2016) verifies this fact by claiming that most Saudi students fail to successfully acquire the English language. Since the sense of self-efficacy of students grows with successes and declines with failures, this affects the learners' perception of their abilities and they accordingly develop low self-efficacy because of their unsuccessful past learning experience.

Another very important reason behind the low self-efficacy of Saudi EFL learners is the absence of Vicarious Experience. The learners usually lack the ability to observe and benefit from other successful people's experiences, which would reinforce their self-belief in their capabilities and in turn enhance their beliefs that they would be able to successfully master similar situations. This situation could be due to the absence of cooperative learning (CL) strategies in teaching English to Saudi university learners, where learners work individually rather than in pairs or groups. Ishtiaq and Hussain (2017) indicated that teachers of English in Saudi universities still adhere to the traditional methods of teaching and that the implementation of CL and other innovative teaching methods is still at an impractical stage. The authors attributed this fact to a variety of reasons such as teachers' unwillingness to change their teaching practices and the lack of appropriate training to apply different CL strategies.

A third rationale for the low efficacy of Saudi language learners could be the lack of Verbal Persuasion. Those learners usually hold self-doubts and lose confidence that they are able to execute learning tasks efficiently (Rafada and Madini, 2017). The learners also hold negative beliefs and expectations about language learning (e.g., Al-Roomy, 2015), which leads consequently to negative self-talk and judgements, especially when they face a learning challenge. Furthermore, those learners lack constant constructive feedback (Alrabai, 2018) and advice from others (e.g., teachers) that would help them maintain a sense of efficacy and offer their best effort to successfully execute learning tasks.

A fourth obstacle that impedes the development of self-efficacy beliefs in Saudi EFL learners is the lack of proper ways of evaluating and dealing with learners' physiological/emotional states such as anxiety, motivation, and attitudes. Dinther, Dochy, and Segers (2011) asserted that students' moods, emotions, physical reactions, and stress levels 
significantly influence their perspectives about their personal abilities and self-efficacy beliefs. These emotions have been found to negatively affect Saudi learners' performance in English language (see Ismail, 2015). A stressful learning environment fuelled by nervousness, tension, low confidence, low motivation, and negative attitudes, as seen in the Saudi EFL context (Asif, 2017), is doubtlessly the perfect environment in which to develop low self-efficacy in learners.

As for the second part of Question 1 of the study, the degree of the learner achievement was classified as follows: an achievement score above 90 out of 100 (>90) was classified as very high achievement; a score from 80 to 90 (80\% to $90 \%$ ) was classified as high achievement; a score from 70 to $80(70 \%$ to $80 \%)$ was classified as moderate achievement; a score from 60 to $70(60 \%$ to $70 \%)$ was classified as low achievement; and an achievement score below $60(<60 \%)$ was classified as very low achievement. The data in Table II reveal that the overall mean score for learner achievement was $66.54(66.54 \%)$. Thus, it can be concluded that Saudi learners are low achievers in terms of the English language. This fact has been confirmed by many prior studies (see e.g. Alhawsawi, 2014; Alrabai, 2017). For detailed explanations of the reasons behind Saudi EFL learners' low language achievement, the reader is referred to these prior studies. One very important conclusion in this study is that learners performed better in comprehension tests (reading and listening) than in performance-based tests (speaking and writing), which emphasizes the deficiencies in their communication skills (See Table II). This finding validates those reported by earlier studies about the difficulties Saudi learners encounter when communicating in a foreign language (See Al-Nasser, 2015; Al-Sobhi and Preece, 2018).

TABLE II.

THE DEGREE OF EFL ACHIEVEMENT OF PARTICIPATING LEARNERS

\begin{tabular}{|l|l|l|}
\hline Variable & Mean & Standard Deviation \\
\hline Achievement in Listening & 70.96 & 11.81 \\
\hline Achievement in Speaking & 52.56 & 8.75 \\
\hline Achievement in Reading & 76.08 & 12.66 \\
\hline Achievement in Writing & 66.56 & 11.07 \\
\hline Overall Achievement & 66.54 (out of 100) & 11.07 \\
\hline
\end{tabular}

2. What is the relationship among learners' self-efficacy and their EFL achievement?

The figures in Table III make it obvious that a positive correlation exists between learners' self-efficacy and their language achievement. This finding suggests that learners' self-efficacy beliefs accounts for their language performance. This conclusion is in line with past research findings that have validated the powerful influence of students' efficacy beliefs on their academic performance (Graham \& Weiner, 1996; Schunk \& Pajares, 2002). In a meta-analysis of self-efficacy research published between 1977 and 1988, Multon, Brown, \& Lent (1991) found positive and significant relationships between self-efficacy beliefs and academic performance. The authors reported that self-efficacy beliefs accounted for approximately $14 \%$ of the variance in students' academic performance.

TABLE III.

THE ASSOCIATION BETWEEN LEARNERS’ SELF-EFFICACY AND THEIR EFL ACHIEVEMENT

\begin{tabular}{|l|l|}
\hline & Overall Achievement \\
\hline Overall Self-efficacy & $.549^{* *}$ \\
\hline \multicolumn{2}{|c|}{ Note. $* *$, Correlation is significant at $\mathrm{p}<0.01}$.
\end{tabular}

\section{CONCLUSIONS AND ReCOMmendations}

This study examined the degree of and the relationship between efficacy of Saudi learners with regard to the English language and their achievement in this language as an academic subject. The EFL learners participated in this study had low self-efficacy and were also low English language achievers. A positive correlation was detected between the two variables. These findings are attributed to a number of reasons such as unsatisfactory mastery experience, lack of Vicarious Experience, lack of verbal persuasion, low motivation, high anxiety, negative attitudes, and low autonomy.

Based on the findings derived from this study, it is obvious that it is necessary to identify the underlying causes of low self-efficacy of Saudi EFL learners to improve their language academic performance. To begin with, the concept of self-efficacy, its sources and benefits should be made clear to both the teachers and students. In addition, efficient and practical methods should be utilized to help students maintain high and positive self-beliefs while learning English. The students must be made aware of the fact that achieving success is directly related to the amount of effort and the self-discipline the learner brings to the task and is not exclusively a function of a person's innate ability. Likewise, failure can be always converted to success by putting in more effort.

Additionally, the sources of self-efficacy should be targeted and addressed. The Mastery Experience of learners should be enhanced in different ways. Kondo (1999) advised that it is necessary to rebuild the self-confidence in learners who have had past failures by creating realistic goals according to their capabilities and interests. In this regard, language teachers are to encourage learners to focus on the external factors that may have contributed to their past failures (e.g., not spending the required time on the task or not following the strategy for learning) rather than blaming their innate learning abilities.

Vicarious Experience of learners should also to be considered. This consideration can be done by using peer models 
in the way that the language instructor forms peers from groups of students according to their age, ethnicity, interests, achievement level, or gender and helps them to obtain benefits from their peer accomplishments.

Verbal persuasion through positive self-talk should also be used to increase learners' self-efficacy. In this respect, certain statements with positivity such as 'I can do it, I will make it, everybody makes mistakes, etc.' may assist in developing learners' self-efficacy. Moreover, teachers must always emphasize learners' capabilities as able students, equip them with frequent, focused, and positive feedback about their progress (Margolis \& McCabe, 2003), and enable them to compare their progress to the desired learning goals. To put this approach into practice, using encouraging statements such as 'you are smart enough to do this, making mistakes is a way of learning' is necessary, though it should be realistic and not exaggerated.

Special attention should be paid to improving learners' physiological/emotional states. Because of the relationship between a learner's self-efficacy and their motivation, it is the teacher's duty to assist students with low motivation to take up challenges and achieve their goals. Linnenbrink and Pintrich (2003) highlighted that behavioural, cognitive and motivational engagements may help develop feelings of efficacy that result in positive changes in the learners' academic performance. Moreover, teachers must find ways to minimize learners' language anxiety. Controlling learners' anxiety helps to build the confidence that they have the ability to achieve their goals and will further provide them with a sense of success and achievement. In this respect, teachers should avoid anxiety-provoking practices such as continuous criticism or comparing the performance of one student to another, which will only increase their anxiety.

Linking the course subjects to the goals, interests, experiences, and values of learners will lead to better attitudes towards learning the target language. These manoeuvres will also assist students in accepting and understanding themselves, thereby enhancing their self-efficacy.

Another technique that might help in dealing with learners' emotions is to help students set specific, short-term, challenging but attainable goals (Pajares \& Schunk, 2002). Students should also be guided to choose learning tasks that are neither too difficult nor too easy. If the learner fails to master tasks that are beyond his/her capability level, this will weaken the learners' self-efficacy. Similarly, if the task accomplished is below the learners' levels of competence, it may not result in efficacy reappraisals (Schunk, 1985).

Students should be involved in an autonomy-supportive environment that enables them to be effectively involved in the learning process. The study of Tilfarlioglu and Ciftci (2011) reported a strong link between learner autonomy and self-efficacy. When participants' sense of self-efficacy increases, their potential to be autonomous also increases.

Although this study bears particular significance for understanding Saudi students' self-efficacy beliefs, limitations exist. First, by limiting the selection of participants to only one university in Saudi Arabia, the study is subject to a threat to external validity. For this reason, the findings of the present study may not be generalizable to other populations. Future research is to recruit participants representing various age and educational levels and different regional backgrounds.

Second, because the study is based on self-reported data, the necessity to conduct further studies cannot be ruled out particularly regarding the learners' English self-efficacy and their beliefs about learning language in Saudi Arabia. Using other data collection tools such as interviews is recommended for future research.

Despite the positive correlation detected in this study between learners' self-efficacy and their EFL performance, its explanatory power of learners' actual performance remains limited due to the limited number of independent variables included in the study. Given that the factors that are associated with language learning outcome are numerous, such as those that go beyond the learner's emotion variables, there remains a necessity to examine the relationship between students' self-efficacy beliefs and other affective variables (the learners' language motivation, aptitude, aptitude, anxiety, attitudes, etc.) to identify the best mediator of language achievement. Future research should investigate how Saudi learners' self-efficacy relates to these factors and how such relationships affect attainment in a foreign language. Finally, researchers' attention needs to be directed towards the value of self-efficacy in promoting the quality of language learning programmes in Saudi Arabia. Further research should also conduct investigations examining the interaction of learners' English self-efficacy with variables such as cognitive styles, learning strategies, motivational constructs; how gender and sex differences influence this variable, and the degree to which using learner-centred learning practices may cause a change in learners' self-efficacy. 


\section{APPENDIX}

\begin{tabular}{|c|c|c|c|}
\hline \\
\hline \\
\hline \multicolumn{4}{|c|}{ 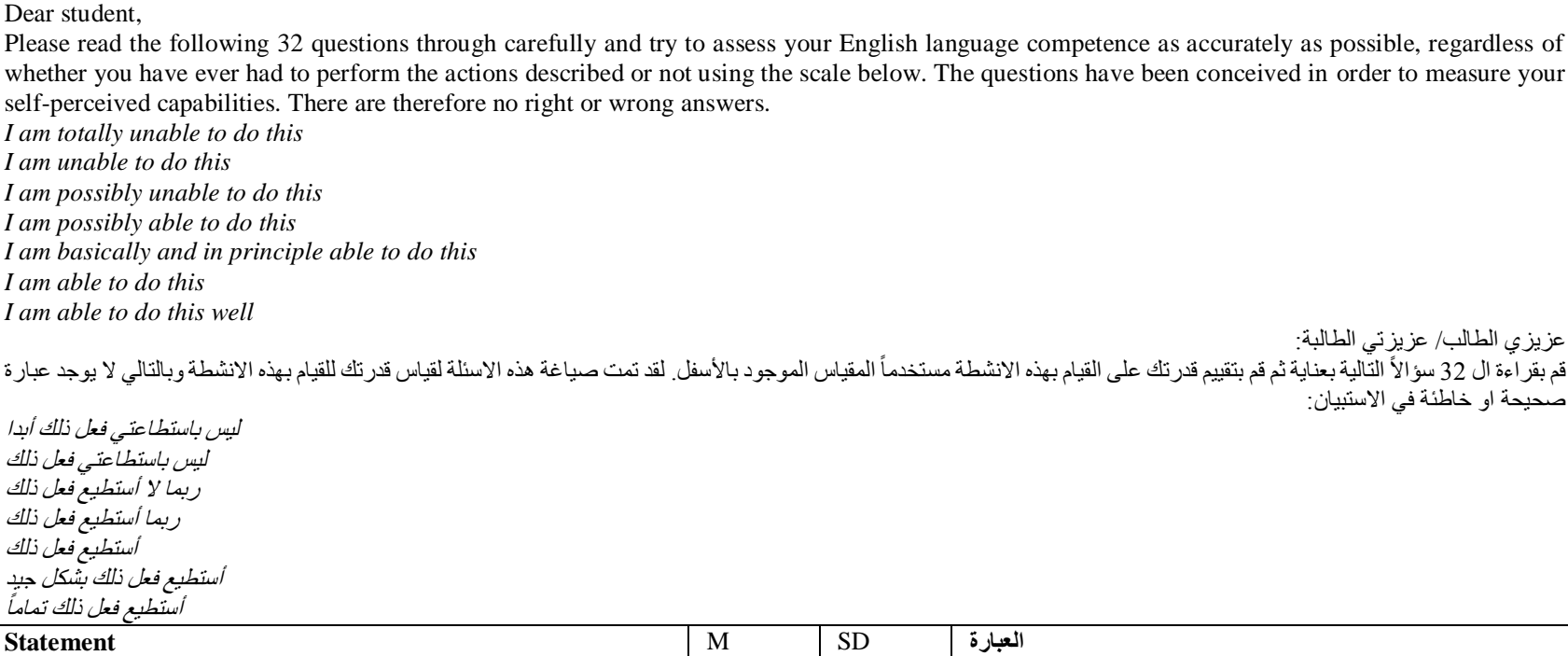 } \\
\hline \\
\hline \multirow{4}{*}{$\begin{array}{l}\text { 2. Can you do homework/home assignments alone when they } \\
\text { include reading English texts? } \\
\text { 3. Can you understand American TV programs (in English)? } \\
\text { 4. Can you describe your university to other people in English? } \\
\text { 5. Can you compose messages in English on the internet } \\
\text { (Facebook and twitter)? }\end{array}$} & 4.28 & 1.22 & 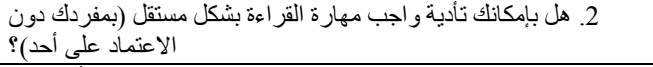 \\
\hline & 3.53 & 1.10 & 3. هل بإكانك فهم البر امج التي تقدم باللغة الانجليزية الأمريكية؟ \\
\hline & 4.2 & & 4. هل بإمكانك وصف مدر ستكاكليتلك باللغة الانجليزية؟ \\
\hline & 4.11 & 1.25 & 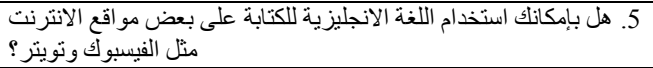 \\
\hline $\begin{array}{l}\text { 6. Can you describe the way to the university from the place } \\
\text { where you live in English? }\end{array}$ & 4.04 & 1.29 & 6. هل بإمكانك وصف الطريق من منزلك الى كليتك باستخدام اللغة" \\
\hline \multirow{3}{*}{$\begin{array}{l}\text { 7. Can you write diary entries in English? } \\
\text { 8. Can you tell a story in English? } \\
\text { 9. Can you understand radio programs in English-speaking } \\
\text { countries? }\end{array}$} & 3.94 & 1.20 & 7. هل بإمكانك كتابة يو مياتك باستخدام اللغة الانجليزية؟ \\
\hline & 3.47 & 29 & 8. هل بإمكانك حكاية قصه لأصدقائك باستخدام اللغة الانجليزية؟ \\
\hline & 3.37 & 1.19 & 9. هل بإمكانك فهم البر امج الإذاعية (عبر الر اديو) الناطقة باللغة الانجليزية؟ \\
\hline \multirow{2}{*}{$\begin{array}{l}\text { 10. Can you understand English-language TV programs? } \\
\text { 11. Can you write a letter or leave a note for another student in } \\
\text { English? }\end{array}$} & 3.59 & & 10 هل بإمكانك فهم البر امج التلفزيونية الناطقة باللغة الانجليزية؟ \\
\hline & 4.40 & 1.14 & 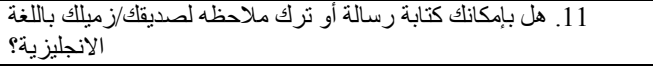 \\
\hline \multirow{2}{*}{$\begin{array}{l}\text { 12. Can you guess the meaning of unknown words when you } \\
\text { are reading an English text? } \\
\text { 13. Can you form new sentences from words you have just } \\
\text { learned? }\end{array}$} & 3.90 & 1.22 & 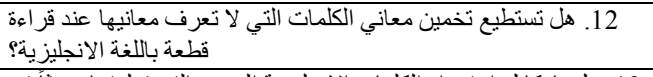 \\
\hline & 4.09 & 1.19 & 13. هل بإمكانك استخدام الكلمات الإنجليزية الجديدة التي تعلمتها حديثاً في جمل \\
\hline \multirow{2}{*}{$\begin{array}{l}\text { 14. Can you write e-mails in English? } \\
\text { 15. Can you understand English dialogs (audio recordings) on a } \\
\text { CD? }\end{array}$} & 3.8 & 5 & 14. هل بإمكانك كتابة بريد الكتروني (ايميل) باللغة الانجليزية؛ \\
\hline & 3.56 & 1.16 & 15. هل بإمكانك فهم محادثه باللغة الانجليزية مسجله على سي دي (CD)؟؟ \\
\hline $\begin{array}{l}\text { 16. Can you understand messages or news items in English on } \\
\text { the internet? }\end{array}$ & 3.33 & 1.14 & 16. هل بإمكانك فهم الأخبار باللغة الانجليزية على الانترنت؟ \\
\hline 17. Can you ask your teacher questions in English? & & 105 & 17. هل بإمكانك توجيه أسئلة لمعلمك باللغة الانجليزية؟ \\
\hline 18. Can you produce English sentences with idiomatic phrases? & 2.78 & 1.19 & 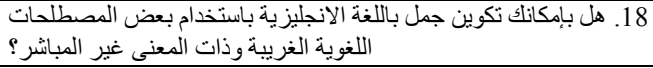 \\
\hline $\begin{array}{l}\text { 19. Can you introduce your teacher (to someone else) in } \\
\text { English? }\end{array}$ & 4.04 & 1.11 & 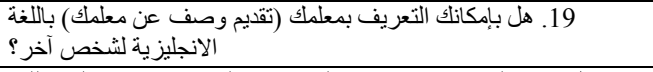 \\
\hline $\begin{array}{l}\text { 20. Can you discuss subjects of general interest with your } \\
\text { fellow students (in English)? }\end{array}$ & 3.74 & 1.27 & 20. هل بإمكانك مناقشة بعض المواضيع العامة مع زملائك باللغة \\
\hline 21. Can you read short English narratives? & 4.53 & o & 21 21. هل بإمكانك قر اءة قصص قصبره باللغة الانجليزية؟ \\
\hline 22. Can you understand English films without Arabic subtitles? & 3.40 & 1.22 & 22 \\
\hline 23. Can you answer your teacher's questions in English? & 4.10 & 1.08 & 23. هل بإمكانك الإجابة باللغة الإنجليزية على الأسئلة التي يوجهها للك \\
\hline 24. Can you understand English songs? & & .21 & 24 24. هل بإكانلك فهم الأغاني باللغة الإنجليزية؟ \\
\hline 25. Can you read English-language newspapers? & 3.54 & 1.24 & 25 25 هل بإمكانك قر اءة جريدة صادره باللغة الإنجليزية؛ \\
\hline $\begin{array}{l}\text { 26. Can you find out the meanings of new words using a } \\
\text { monolingual dictionary? }\end{array}$ & 3.83 & 1.28 & 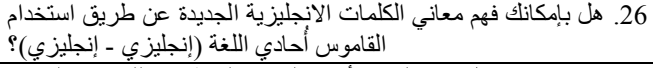 \\
\hline 27. Can you understand telephone numbers spoken in English? & 4.7 & 1.09 & 27 \\
\hline 28. Can you post news in English on the internet? & 2.91 & 1.20 & 28 \\
\hline 29. Can you understand English articles on Arabic culture? & 3.40 & 1.31 & 29 هل بإمكانك فهم مقاله عن الثقافة العربية مكتو به باللغة الانجليزية؟ \\
\hline 30. Can you introduce yourself in English? & 5.00 & 1.10 & 30 هل بإمكانك التعريف بنفسك (تقديم وصف عن نفسك) باللغة الانجليزية؟ \\
\hline $\begin{array}{l}\text { 31. Can you write an essay in about two pages about your } \\
\text { school/college in English? }\end{array}$ & 3.39 & 1.37 & 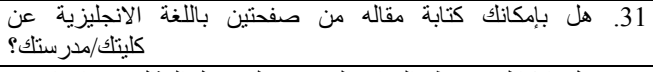 \\
\hline $\begin{array}{l}\text { 32. Can you understand new reading materials (e.g., news from } \\
\text { Arab news newspaper) selected by your instructor? }\end{array}$ & 3.60 & 1.19 & 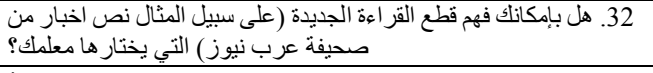 \\
\hline
\end{tabular}




\section{REFERENCES}

[1] Abdelhafez, A. \& H. Zaki. (2016). EFL university students' self-efficacy and its relationship to their identity. Journal of Modern Education Review 6.10, 739-756.

[2] Alaraj, M. M. (2016). EFL acquisition external problems and difficulties: An investigative interview to examine Saudi students' thoughts and feelings. Journal of Language Teaching and Research 7.3, 484-490. doi:10.17507/j1tr.0703.07.

[3] Alhawsawi, S. (2013). Investigating student experiences of learning English as a foreign language in a preparatory programme in a Saudi university. Doctoral dissertation, University of Sussex.

[4] Al-Nasser, A. S. (2015). Problems of English language acquisition in Saudi Arabia: An exploratory-cum-remedial study. Theory and Practice in Language Studies 5.8, 1612-1619. doi:10.17507/tpls.0508.10.

[5] Alrabai, F. (2017). Self-esteem of Saudi learners and its relationship to their achievement in English as a foreign language. English Linguistics Research 6.4, 1-12. doi:10.5430/elr.v6n4p1.

[6] Alrabai, F. (2018). Learning English in Saudi Arabia. In C. Moskovsky \& M. Picard (Eds.), English as a Foreign Language in Saudi Arabia: New Insights into Teaching and Learning English (pp. 102-119). London: Routledge

[7] Al-Roomy, M. (2015). Evaluating Saudi university students' beliefs about learning English. International Journal of English Linguistics 5.1, 22-31. doi:10.5539/ijel.v5n1p22.

[8] Al-Sobhi, B. M. \& A. S. Preece. (2018). Teaching English speaking skills to the Arab students in the Saudi school in Kuala Lumpur: Problems and solutions. International Journal of Education \& Literacy Studies 6.1, 1-11. doi:10.7575/aiac.ijels.v.6n.1p.1.

[9] Asakereh, A. \& M. Dehghannezhad. (2015). Student satisfaction with EFL speaking classes: Relating speaking self-efficacy and skills achievement. Issues in Educational Research 25.4, 345-363.

[10] Asif, F. (2017). The anxiety factors among Saudi EFL learners: A study from English language teachers' perspective. English Language Teaching 10.6, 160-173. doi:10.5539/elt.v10n6p160.

[11] Ayoobiyan, H. \& T. Soleimani. (2015). The relationship between self-efficacy and language proficiency: A case of Iranian medical students. Journal of Applied Linguistics and Language Research 2.4, 158-167.

[12] Bandura, A. (1986). Social foundation of thoughts and action: A social cognitive theory. Englewood Cliffs, NJ: Prentice-Hall.

[13] Bandura, A. (1997). Self-efficacy: The exercise of control. New York, NY: W. H. Freeman / Times Books / Henry Holt \& Co.

[14] Bernhardt, S. (1997). Self-efficacy and second language learning. The NCLRC Language Resource 1.5.

[15] Blumenthal, L. F. (2014). Self-efficacy in low-level English language learners. Doctoral dissertation, Portland State University.

[16] Boakye, N. (2015). The relationship between self-efficacy and reading proficiency of first-year students: An exploratory study. Reading \& Writing 6.1, 1-9. doi:10.4102/rw.v6i1.52.

[17] Branscombe, N. R. \& R. A. Baron. (2016). Social psychology. New York, NY: Pearson.

[18] Chen, H. Y. (2007). The relationship between EFL Learners' self-efficacy beliefs and English performance. Unpublished PhD Thesis, Florida State University.

[19] Chen, M. C. \& H. J. Lin. (2009). Self-efficacy, foreign language anxiety as predictors of academic performance among professional program students in a general English proficiency writing test. Perceptual and Motor Skills 109.2, 420-430. doi:10.2466/pms.109.2.420-430.

[20] Dinther, M. V., F. Dochy \& M. Segers. (2011). Factors affecting students' self-efficacy in higher education. Educational Research Review 6.2, 95-108. doi:10.1016/j.edurev.2010.10.003.

[21] Graham, S. \& B. Weiner. (1996). Theories and principles of motivation. In: D. C. Berliner \& R. C. Calfee (eds.), Handbook of educational psychology. New York, NY: Simon \& Schuster Macmillan, 63-84.

[22] Herron, C., N. Mills \& F. Pajares. (2006). A reevaluation of the role of anxiety: Self-efficacy, anxiety, and their relation to reading and listening proficiency. Foreign Language Annals 39.2, 273-292.

[23] Huang, S. C. \& S. F. Chang. (1998). Self-efficacy in learners of English as a second language: Four examples. Journal of Intensive English Studies 12, 23-40.

[24] Ishtiaq, M. \& M. Hussain. (2017). Scope of cooperative learning (CL) strategies in teaching English to Saudi adult EFL learners: A study of practical barriers and possible implications. International Journal of Applied Linguistics \& English Literature 6.7, 110-121. doi:10.7575/aiac.ijalel.v.6n.7p.110.

[25] Ismail, N. M. (2015). EFL Saudi students' class emotions and their contributions to their English achievement at Taif University. International Journal of Psychological Studies 7.4, 19-42. doi:10.5539/ijps.v7n4p19.

[26] Kondo, K. (1999). Motivating bilingual and semi bilingual university students of Japanese: An analysis of language learning persistence and intensity among students from immigrant backgrounds. Foreign Language Annals 32.1, 77-88. doi:10.1111/j.1944-9720.1999.tb02377.x.

[27] Linnenbrink, E. A. \& P. R. Pintrich. (2003). The role of self-efficacy beliefs in student engagement and learning in the classroom. Reading \& Writing Quarterly 19.2, 119-137. doi:10.1080/10573560308223.

[28] Mahyuddin, R. et al. (2006). The relationship between students' self-efficacy and their English language achievement. Jurnal Pendidik dan Pendidikan 21, 61-71.

[29] Margolis, H. \& P. P. McCabe. (2004). Self-efficacy: A key to improving the motivation of struggling learners. Preventing School Failure: Alternative Education for Children and Youth 77.6, 241-249. doi:10.3200/TCHS.77.6.241-249.

[30] Mills, N., F. Pajares \& C. Herron. (2007). Self-efficacy of college intermediate French students: Relation to achievement and motivation. Language Learning 57.3, 417-442. doi:10.1111/j.1467-9922.2007.00421.x.

[31] Multon, K. D., S. D. Brown \& R. W. Lent. (1991). Relation of self-efficacy beliefs to academic outcomes: A meta-analytic investigation. Journal of Counseling Psychology 38.1, 30-38. doi:10.1037/0022-0167.38.1.30.

[32] Pajares, F. (1996). Assessing self-efficacy beliefs and academic success: The Case for specificity and correspondence. In B. J. Zimmerman (ed.), Annual meeting of the American educational research association. New York, NY.

[33] Pajares, F. (2003). Self-efficacy beliefs, motivation, and achievement in writing: A review of the literature. Reading and Writing Quarterly 19.2, 139-158. doi:10.1080/10573560308222. 
[34] Pajares, F. (2009). Motivational role of self-efficacy beliefs in self-regulated learning. In D. H. Schunk \& B. J. Zimmerman (eds.), Motivation and self-regulated learning: Theory, research, and applications. New York, NY: Routledge, 111-139.

[35] Pajares, F. \& M. Miller. (1995). Mathematics self-efficacy and mathematics performances: The need for specificity of assessment. Journal of Counseling Psychology 42.2, 190-198. doi:10.1037/0022-0167.42.2.190.

[36] Pajares, F., M. Miller \& M. J. Johnson. (1999). Gender differences in writing self-beliefs of elementary school students. Journal of Educational Psychology 91.1, 50-61. doi:10.1037/0022-0663.91.1.50.

[37] Pajares, F. \& D. Schunk. (2002). Development of academic self-efficacy. In: A. Wigfield \& J. Eccles (eds.), Development of achievement motivation. San Diego, CA: Academic Press, 16-31.

[38] Pajares, F. \& G. Valiante. (1997). Influence of self-efficacy on elementary students' writing. The Journal of Educational Research 90.6, 353-360. doi:10.1080/00220671.1997.10544593.

[39] Pintrich, P. R. \& D. H. Schunk. (1996). Motivation in education: Theory, research, and applications. Englewood Cliffs, NJ: Prentice-Hall.

[40] Rabab'ah, G. (2003). Communication problems facing Arab learners of English. Journal of Language and Learning 3.1, 180-197.

[41] Rafada, S. \& A. Madini. (2017). Effective solutions for reducing Saudi learners' speaking anxiety in EFL classrooms. Arab World English Journal 8.2, 308-322. doi:10.24093/awej/vol8no2.22.

[42] Rahimi, A. \& A. Abedini. (2009). The interface between EFL learners' self-efficacy concerning listening comprehension and listening proficiency. Novitas-ROYAL 3.1, 14-28.

[43] Schunk, D. H. (1985). Self-efficacy and classroom learning. Psychology in the Schools 22.2, $208-223$. doi:10.1002/1520-6807(198504)22:2<208::AID-PITS2310220215>3.0.CO;2-7.

[44] Schunk, D. H. (1990). Goal setting and self-efficacy during self-regulated learning. Educational Psychologist 25.1, 71-86. doi:10.1207/s15326985ep2501_6.

[45] Schunk, D. H. (1991). Self-efficacy and academic motivation. Educational Psychologist 26.3-4, $207-231$. doi:10.1080/00461520.1991.9653133.

[46] Schunk, D. H. \& F. Pajares. (2002). The development of academic self-efficacy. In A. Wigfield \& J. Eccles (eds.), Development of achievement motivation. San Diego, CA: Academic Press, 16-31.

[47] Siddiqui1, S. (2015). Impact of self-efficacy on psychological well-being among undergraduate students. The International Journal of Indian Psychology 2.3, 5-16.

[48] Siegle, D. (2000). An Introduction to Self-Efficacy. Retrieved 28/04/2018, from https://nrcgt.uconn.edu/underachievement_study/self-efficacy/se_section1/\#

[49] Tilfarlioglu, F. \& F. Ciftci. (2011). Supporting self-efficacy and learner autonomy in relation to academic success in EFL classrooms (A Case Study). Theory and Practice in Language Studies 1.10, 1284-1294. doi:10.4304/tpls.1.10.1284-1294.

[50] Tremblay, P. F. \& R. C. Gardner (1995). Expanding the motivation construct in language learning. The Modern Language Journal 79.4, 505-518. doi:10.2307/330002.

[51] Usher, E. L. (2009). Sources of middle school students' self-efficacy in mathematics: A qualitative investigation. American Educational Research Journal 46.1, 275-314. doi:10.3102/0002831208324517.

[52] Wang, C. (2004). Self-regulated learning strategies and self-efficacy beliefs of children learning English as a second language. Doctor of Philosophy, The Ohio State University.

[53] Wang, C., D.-H. Kim, M. Bong \& H. S. Ahn. (2013). Examining measurement properties of an English self-efficacy scale for English language learners in Korea. International Journal of Educational Research 59, 24-34. doi:10.1016/j.ijer.2013.02.004.

[54] Zimmerman, B. J. (1995). Self-efficacy and educational development. In A. Bandura (ed.), Self-efficacy in changing societies. New York, NY: Cambridge University Press, 202-231.

[55] Zuo, H. \& C. Wang. (2016). Understanding sources of self-efficacy of Chinese students learning English in an American institution. Multicultural Learning and Teaching 11.1, 83-112.

Fakieh Alrabai is an Associate Professor of Applied Linguistics at King Khalid University, Saudi Arabia. He holds a PhD degree in Applied Linguistics from the University of Newcastle, NSW, Australia. Research areas: Applied Linguistics, Second Language Acquisition (SLA), Psycholinguistics, L2 Motivation, learner autonomy, and Language anxiety. 